\title{
THE INFLUENCE OF STUDENTS' ATTITUDE AND PERCEPTION ON SCIENTIFIC APPROACH TOWARD THEIR ENGLISH ACHIEVEMENT AT SMA MUHAMMADIYAH 11 PADANGSIDIMPUAN
}

\author{
${ }^{1}$ Diena Fitria \\ ${ }^{1}$ UIN Sultan Syarif Kasim Riau, Indonesia \\ Email: ${ }^{\text {diena@gmail.com }}$
}

Received: 30 Oktober 2019; Accepted 28 Mei 2021; Published 31 Mei 2021

Ed 2021; 2(1): 145-158

\begin{abstract}
ABSTRAK
Tujuan penelitian ini untuk mengetahui pengaruh Sikap dan Persepsi Siswa dalam Penerapan Pendekatan Ilmiah terhadap Prestasi Bahasa Inggris di SMA Muhammadiyah 11 Padangsidimpuan. Penelitian ini merupakan penelitian korelasional expo facto dengan menggunakan dua variabel bebas dan satu variabel terikat, sikap siswa (X1) dan persepsi (X2) sebagai variabel bebas, dan prestasi bahasa Inggris (Y) sebagai variabel terikat. Tiga pertanyaan penelitian dikemukakan dalam penelitian ini. Responden siswa kelas XI SMA Muhammadiyah 11 Padangsidimpuan sebanyak 41 responden. Total sampling digunakan dalam penelitian ini karena jumlah siswanya tidak terlalu banyak. Data sikap dan persepsi siswa dikumpulkan dengan menggunakan angket skala likert, sedangkan prestasi siswa diambil dari data yang terdokumentasi. Analisis data menggunakan rumus Product-Moment dan analisis varian untuk data regresi berganda. Tiga hipotesis dikemukakan dalam penelitian ini. Hasil hipotesis pertama menunjukkan bahwa sikap siswa terhadap prestasi belajar bahasa Inggris memiliki pengaruh yang lebih signifikan dibandingkan dengan hipotesis kedua tentang pengaruh persepsi siswa melalui pendekatan saintifik terhadap prestasi belajar bahasa Inggris siswa. Dari hasil penelitian dapat disimpulkan bahwa ada pengaruh yang signifikan sikap dan persepsi siswa terhadap prestasi belajar bahasa Inggris siswa di SMA Muhammadiyah 11 Padangsidimpuan.
\end{abstract}

Kata kunci: sikap siswa, persepsi, pendekatan saintifik, prestasi belajar bahasa inggris.

\section{THE INFLUENCE OF STUDENTS' ATTITUDE AND PERCEPTION ON SCIENTIFIC APPROACH TOWARD THEIR ENGLISH ACHIEVEMENT AT SMA MUHAMMADIYAH 11 PADANGSIDIMPUAN}

\begin{abstract}
The purpose of this study was found out the influence of Students' Attitude and Perception on Implementing the Scientific Approach Toward their English Achievement at SMA Muhammadiyah 11 Padangsidimpuan. This study was a correlational research design of expo facto using two independent variables and one dependent variable, Students' attitude (X1) and Perception (X2) were independent variables, and English achievement (Y) as dependent variable. Three research questions were stated in this research. There were 41 respondents of the eleventh grade students of SMA Muhammadiyah 11 Padangsidimpuan.
\end{abstract}


Total sampling was used in this research because the number of students was not so many. Data of students' attitude and perception were collected using questionnaires of Likert's scale, while the students' achievement was taken from a documented data. The data were analysed by using Product-Moment formula and the analysis of variance for multiple regressions data. Three hypotheses were stated in this research. The result of the first hypothesis is showed that students' attitude toward English achievement had more significant influence compared to the second hypothesis of the influence of the students' perception through scientific approach on students' English achievement. At last, the finding can be concluded that there were significant influences of students' attitude and perception toward the English achievement of the students at SMA Muhammadiyah 11 Padangsidimpuan.

Keyword: Students' attitude, perception, scientific approach, English achievement.

\section{INTRODUCTION}

Attitude is an essential factor which influences success or failure for learners. This statement is also supported by Khoir (2014: 1), he says that one of part that can indicate the successful or unsuccessful learning a foreign language is students' language attitude. It plays a major role in arousing students' interest and motivation to learn a second language (BaUdhan, 2011: 151). It facilitates self-assessment and guides us to behave appropriately. Good attitude correlates with good result that is applicable in language learning. It means that if the learner has a good attitude toward learning foreign language, they will be more likely to be successful in achieving the target language. According to Walqui (2000) in her book, she says that the factors affecting language learning from the perspective of the learner can be mentioned as diverse needs and goals, peer groups, role models, starting age for language learning and pre-school support. From the perspective of the learning process, the factors influencing language learning could be outlined as learning styles and strategies, motivation, attitude and classroom interaction. Khoir (2014:2) states that the language attitude is normally in line between thought and act. It means that, if a person has a positive attitude toward the language, will behave positively to the language. Then, when a person has positive attitude but the act is negative, it is commonly called a gap. It happens when the difference between the mind and the behaviour of students. In this case, the students may say they are proud of learning English but they feel ashamed when they are speaking in English.

Another factor that influences English achievement was students' perception. Huffman and Vernoy (2000:113) have stated that perception is the process of selecting, organizing, and interpreting sensory data into useable mental representation of the world. On the other hand, Worchel and Shebilske (1989, p.68) state that perception is the process of interpreting information. Thus, perception is an action in which someone gives the stimulus and response about something which happens in the reality. Actually, the word Perception comes from the Latin words perception, "percipio", meaning "receiving", collecting, and action of taking possession, apprehensionwith the mind or senses". In psychology, philosophy and the cognitive sciences, perceptionis the process of attaining awareness or understanding of sensory information.In biology, perception is understood as "the mental interpretation of physical sensations produced by stimuli from the outside word". Here 'mental interpretation' has been interpreted as a process of constructingan internal model of the environment.

The government in Indonesia has paid attention to the education for a long time. It can be seen from the curriculum that has changed several times in order to improve the quality national of education and creates a qualified students based on the development era. A curriculum has a very important role as a guidance to succeed for an educational system. 
Without an appropriate curriculum, it will be difficult to achieve the objectives of educational progress. The curriculum changes have the different educational goals, because in every change there is a specific goal to be achieved to advance the national education. The Ministry of Education and Culture of Indonesia has recently published the new curriculum, called the 2013 curriculum. This curriculum change is obviously expected to be able to develop Indonesia education in this globalization era.

The problems of students that are about attitude and perception in step of the scientific approach and the influence of students' attitude and perception to their achievement, which is known as the scientific approach consists of five steps, they are observing, questioning, associating, experimenting, and networking. In observing the students are directly involved in learning. It helps teachers to contextualize students' learning in the classroom but in fact the students in observing step they do not fully pay attention to what the teacher asks them to observe either media or video, and the students feel confused to give question to the teacher based on the media or video. In associating the students feel confused that what they want to do after observing, questioning so they don't have something to associate. In networking or communicating the students can write their work on the board forward one by one, in this step sometime the teacher has limited time to ask students one by one. In fact steps in scientific approach the learning pattern are not teacher-centred but student-centred and one direction interaction between teacher and students to interactive learning., so this way make the researcher wants to explore the perception of the students about the implementation of scientific approach. From above explanation, this research tries to find out "The Influence of Students' Attitude and Perception on Implementing Scientific Approach Toward their English Achievement at SMA Muahammadiyah 11 Padangsidimpuan."

\section{RESEARCH METHODOLOGY}

This research used ex post facto design and was categorized into correlational research. Ex post facto attempts to understand relationships among phenomena as they naturally occur without any researcher intervention. Furchan (2007:410) gives the definition of the ex-post facto research as the systematically empirical research where the researcher does not control the independent variable directly because it happens previously; or basically it cannot be manipulated. The inference of the relationship between the variables is done without a direct intervention from the accompanying or concomitant variation of the independent variable and dependent variable. It was conducted through a quantitative approach. In this term of quantitative data, statistical analysis would be used to calculate the numeral data that were gathered and to analyze them by the use of correlation analysis. The quantitative approach would be used to obtain the relationship between students' attitude and creativity in learning English toward English achievement at Senior High School or SMA Muhammadiyah 11 Padangsidempuan. The target of population of this research was the twelveth year students of SMA Muhammadiyah 11 Padangsidimpuan. They consisted of two classes of each grade. The duration of this study was one month from 9 to 8 April 2019.

\section{RESULTS AND DISCUSSION}

According to Pallant (2010), if group of students to be researched appropriate analyzing is correlation statistical analysis. Three levels of correlation first small correlation (0.1 up to 0.29$)$, medium correlation (0.3 up to 0.49$)$ and high correlation (0.5 up to 1$)$. 
Table IV.1 Correlations

\begin{tabular}{|l|l|r|c|c|}
\hline & & $\begin{array}{c}\text { Students' } \\
\text { achievemen } \\
\text { t }\end{array}$ & $\begin{array}{c}\text { Students, } \\
\text { Attitude }\end{array}$ & $\begin{array}{c}\text { Students' } \\
\text { perception on } \\
\text { scientific } \\
\text { Approach }\end{array}$ \\
\hline $\begin{array}{l}\text { Pearson } \\
\text { Correlatio } \\
\mathrm{n}\end{array}$ & Student achievement & 1.000 & .678 & .347 \\
\hline & Student attitude & .678 & 1.000 & .663 \\
\hline & $\begin{array}{l}\text { Student perception on } \\
\text { scientific approach }\end{array}$ & .347 & .663 & 1.000 \\
\hline $\begin{array}{l}\text { Sig. }(1- \\
\text { tailed) }\end{array}$ & Student achievement &. & .000 & .013 \\
\hline & Student attitude & .000 &. & .000 \\
\hline & $\begin{array}{l}\text { Student perception on } \\
\text { scientific approach }\end{array}$ & .013 & .000 &. \\
\hline $\mathrm{N}$ & Student achievement & 41 & 41 & 41 \\
\hline & Student attitude & 41 & 41 & 41 \\
\hline & $\begin{array}{l}\text { Student perception on } \\
\text { scientific approach }\end{array}$ & 41 & 41 & 41 \\
\hline
\end{tabular}

IV.1. Correlation shows that students' English achievement has a relationship to students; attitude with $\mathrm{P}$ value is 0.00 smaller than 0.05 . with strength is high correlation $(0.678)$. English achievement has a relationship to students; perception of scientific approach with $\mathrm{P}$ value is 0.01 smaller than 0.05 . with strength is medium correlation (0.347). It can be inferred that students' perception on scientific approach has a relationship to student attitude with $\mathrm{P}$ value is 0.00 smaller than 0.05 . with strength is high correlation (0.678).

Table IV.2 Descriptive Statistics

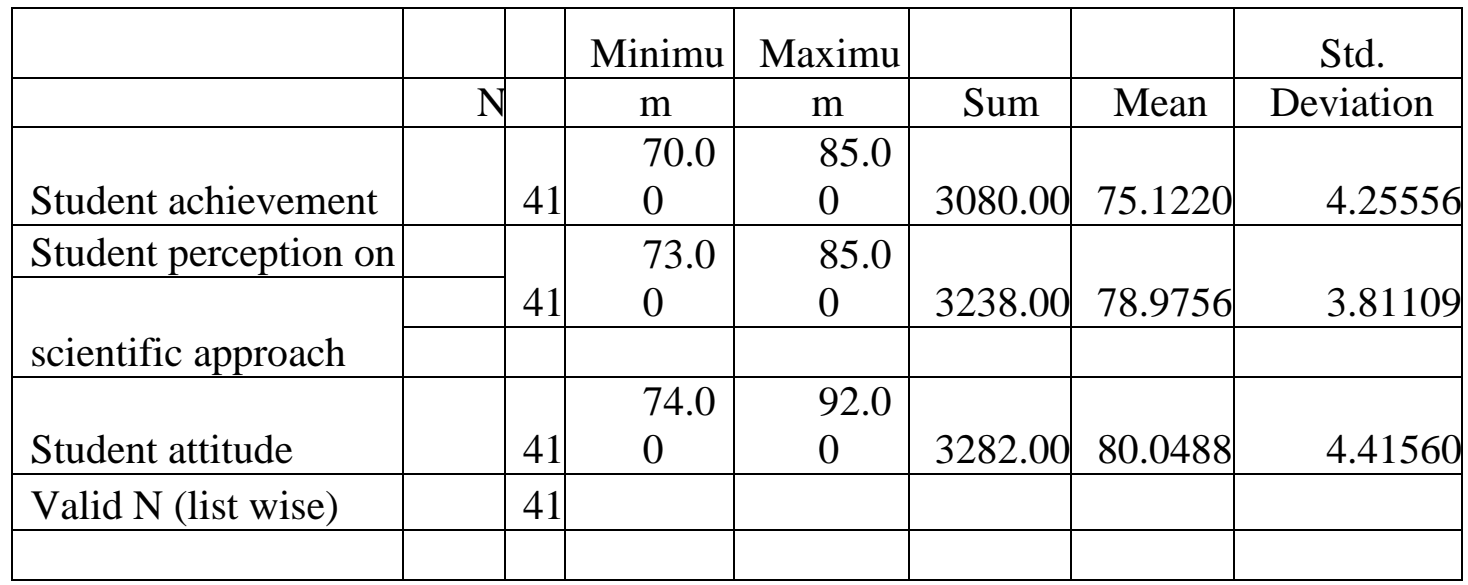

Furthermore, normal P.P Plot of regression standardized residual dependent variable of students' English achievement can be seen in the following scatter plot: 


\section{SCATTER PLOT 1}

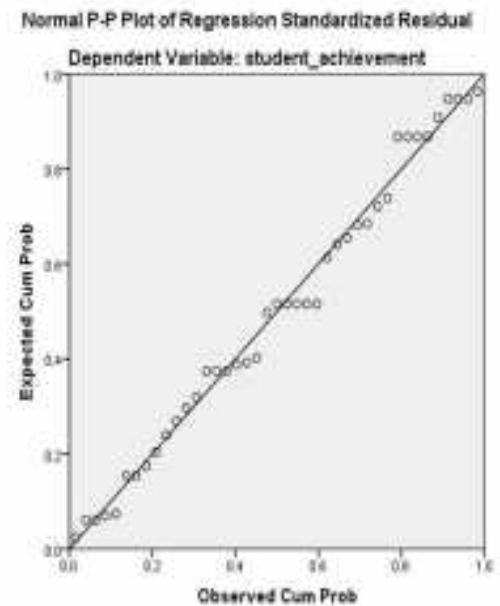

Gambar 4.1 Hypothesis Testing

Based on the finding of data analysis of correlation and Analysis of Variance (ANOVA), it can be determined as follows:

1. Ha1: There is a significant influence of students' attitude on implementing scientific approach toward their English achievement at SMA 11 Muhammadiyah Padangsidimpuan

Ho1: There is no a significant influence of students' attitude on implementing scientific approach toward English achievement at SMA 11 Muhammadiyah Padangsidimpuan

In this study, Hal is accepted if $\mathrm{p}>\alpha(\mathrm{p}=$ the significant score of students, $\alpha=$ the significant level), and it uses level of significance of 0.05 . The data are correlated by using Pearson Product Moment Correlation (SPSS) in order to investigate whether there is any correlation or not. The first hypothesis can be proved by statistical analysis using correlation. Based on the data, it can be seen that Mean $(\mathrm{Mx})$ and Standard deviation $(\delta)$ of students' attitude are 86.42 with calculation $100 \%$ and 12.47, while the Mean (Mx) and Standard Deviation of achievement are 80.38 and 4.004. It is also explained on the table below:

Table.IV.3

Descriptive Statistics

Correlations

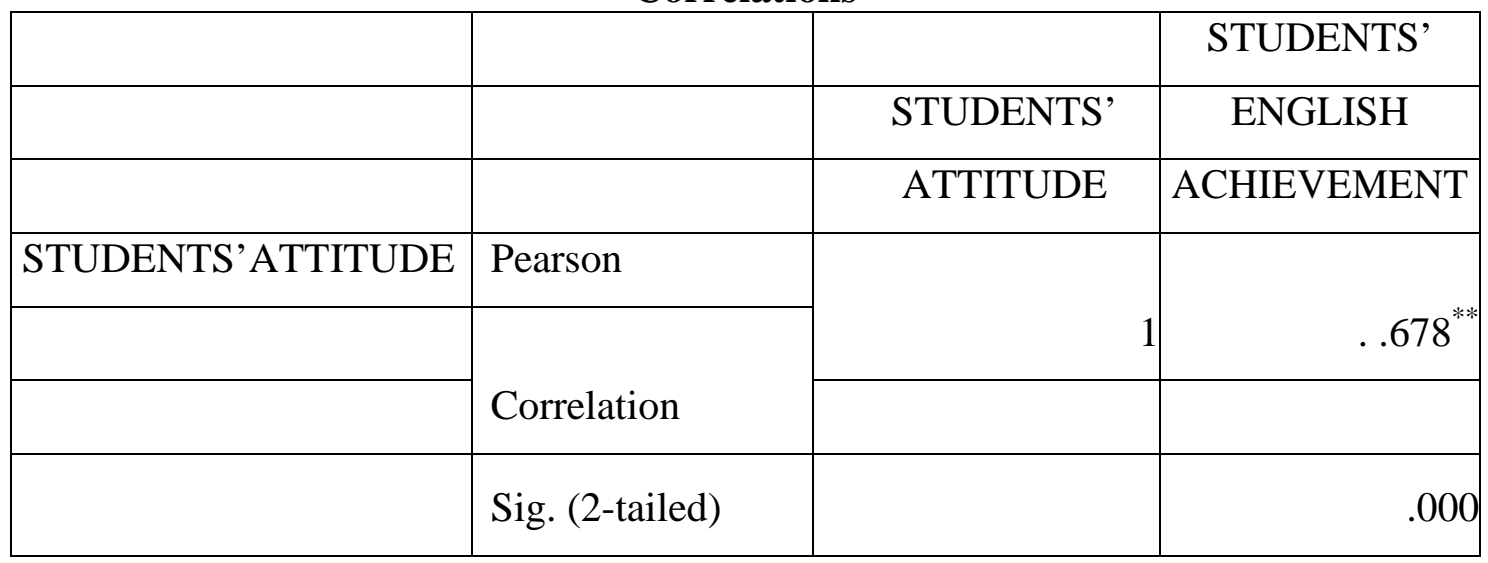




\begin{tabular}{|l|l|r|r|}
\hline & $\mathrm{N}$ & 41 & 41 \\
\hline STUDENTS' ENGLISH & Pearson & & \\
\hline \multirow{2}{*}{ ACHIEVEMENT } & Correlation & $.347^{* *}$ & 1 \\
\hline & Sig. (2-tailed) & & \\
\hline & $\mathrm{N}$ & .000 & 41 \\
\hline
\end{tabular}

Table.IV.3

Descriptive Statistics

Correlations

\begin{tabular}{|c|c|c|c|}
\hline & & & STUDENTS' \\
\hline & & STUDENTS' & ENGLISH \\
\hline & & ATTITUDE & ACHIEVEMENT \\
\hline \multirow[t]{5}{*}{ STUDENTS'ATTITUDE } & Pearson & & \\
\hline & \multirow[b]{2}{*}{ Correlation } & 1 & $678^{* *}$ \\
\hline & & & \\
\hline & Sig. (2-tailed) & & .000 \\
\hline & $\mathrm{N}$ & 41 & 41 \\
\hline STUDENTS' ENGLISH & Pearson & & \\
\hline \multirow{4}{*}{ ACHIEVEMENT } & & $.347^{* * *}$ & 1 \\
\hline & Correlation & & \\
\hline & Sig. (2-tailed) & .000 & \\
\hline & $\mathrm{N}$ & 41 & 41 \\
\hline & & & \\
\hline
\end{tabular}

**. Correlation is significant at the 0.01 level (2-tailed).

Based on the table above, it can be seen that the value of Pearson correlation is 0.678 , the value of Sig. (2-tailed) is 0.000 , and total number of students is 41 . By orienting number of significance, if probability $>0.05$, null hypothesis $(\mathrm{H} 0)$ is rejected. If probability $<0.05$ alternative hypothesis (Ha) is accepted. So, by looking at the value of Sig. (2-tailed) that is < than $\alpha$ (the significant level) it can be said that there is a significant influence between students' attitude and achievement because of the value of sig. (2-tailed) is $0.000<0.05$, and also the value of Pearson correlation, it is higher than ttable by comparing it at significant level $5 \%$ or $0.678>0.347$. This kind of Pearson correlation includes positive influence. It 
means that when students have good attitude then followed by going up of students' achievement or on the contrary when students have bad attitude then followed by going down of the students' achievement. Then, by looking at the value of Pearson correlation (0.678), it can be interpreted that correlation between students' attitude and achievement is high correlation.

In conclusion, hypothesis alternative (Ha1) is accepted. So, there is an influence of students' attitude on implementing scientific approach toward students' English achievement of the second level of SMA Muhammadiyah 11 Padangsidimpuan.

\section{Hypothesis 2}

2. Ha2: There is a significant influence of students' perception on implementing scientific approach toward their English Achievement at SMA Muhammadiyah 11 Padangsidimpuan.

Ho2: There is no a significant influence of students' perception on implementing scientific approach toward their English Achievement at SMA Muhammadiyah 11 Padangsidimpuan.

The second hypothesis can be proved by statistical analysis using correlation. It is explained on the table below: Based on the data, the Mean (Mx) and Standard deviation $(\delta)$ of perception are 86.93 and 11.967, while the Mean (Mx) and Standard Deviation achievement are 80.38 and 4.004 . It can be seen on the table below:

Table: IV.4

\section{Correlations}

\begin{tabular}{|c|c|c|c|}
\hline & & & STUDENTS \\
\hline & & STUDENTS' & ENGLISH \\
\hline & & PERCEPTION & ACHIEVEMENT \\
\hline \multirow[t]{6}{*}{$\begin{array}{l}\text { STUDENTS } \\
\text { PERCEPTION }\end{array}$} & Pearson & \multirow{3}{*}{ 2010 } & \multirow[b]{2}{*}{$.663^{* *}$} \\
\hline & \multirow[b]{2}{*}{ Correlation } & & \\
\hline & & & \\
\hline & Sig. (2-tailed) & & .000 \\
\hline & $\mathrm{N}$ & \multirow[b]{2}{*}{41} & \multirow[t]{2}{*}{41} \\
\hline & & & \\
\hline $\begin{array}{l}\text { STUDENTS } \\
\text { ENGLISH }\end{array}$ & Pearson & \multirow{3}{*}{$.347^{* *}$} & \\
\hline \multirow{4}{*}{$\begin{array}{l}\text { ACHIEVEME } \\
\text { NT }\end{array}$} & \multirow{2}{*}{ Correlation } & & \\
\hline & & & 1 \\
\hline & Sig. (2-tailed) & .000 & \\
\hline & $\mathrm{N}$ & 41 & 41 \\
\hline
\end{tabular}

**. Correlation is significant at the 0.01 level (2-tailed). 
Based on the table above, it can be seen that the value of Pearson correlation is 0.663 , the value of Sig. (2-tailed) is 0.000 , and total number of students is 41 . By looking at the value of Sig. (2-tailed) that is < than $\alpha$ (the significant level) it can be said that there is a significant influence between students' perception and achievement because of the value of sig. (2tailed) is $0.000<0.05$, it can be said that there is a significant influence between students' perception and achievement, and also the value of Pearson correlation, it is higher than ttable by comparing it at significant level $5 \%$ or $0.663>0.347$. This kind of Pearson correlation includes positive influence. It means that when students have high perception

then followed by going up of students' achievement or on the contrary when students have low perception then followed by going down of the students' achievement. Then, by looking at the value of Pearson correlation (0.663), it can be interpreted that correlation between students' perception and achievement is high correlation. In conclusion, hypothesis alternative (Ha1) is accepted. So, there is an influence of students' perception on students' English achievement of SMA 11 Muhammadiyah Padangsidimpuan.

\section{Hypothesis 3} follows:

Based on the theories and assumption above, the study proposes the hypothesis as

3. Ha3: There is a significant influence of students' attitude and perception on implementing scientific approach toward their English achievement at SMA 11 Muhammadiyah Padangsidimpuan.

Ho3: There is no a significant influence of students' attitude and perception on implementing scientific approach toward their English achievement at SMA 11 Muhammadiyah Padangsidimpuan.

The third hypothesis can be proved by statistical analysis using multiple regressions. It is explained on the table below:

Table: IV.5

Model Summary

\begin{tabular}{|c|c|c|c|c|}
\hline & & & Adjusted R & Std. Error of \\
\hline Model & $\mathrm{R}$ & R Square & Square & the Estimate \\
\hline 1 & $.724^{\mathrm{a}}$ & .377 & .346 & 3.425 \\
\hline & & & & \\
\hline
\end{tabular}

a. Predictors: (Constant), STUDENTS' PERCEPTION, STUDENTS' ATTITUDE

The table above explains the percentage of the influence students' attitude and perception on implementing scientific approach toward English achievement. The value of R Square is 0.724, it means that the influence of students' attitude and perception toward English achievement is $72.4 \%$. And an adjusted $\mathrm{R}$ square of 0.377 , this means that attitude and perception combined together to significantly influence the English achievement of the students.

To determine whether there is significant influence or not of students' attitude and perception toward students' English achievement, it can be seen from table below: 
Table IV.6

\begin{tabular}{|c|c|c|c|c|c|c|c|}
\hline \multicolumn{8}{|c|}{ ANOVA $^{a}$} \\
\hline & & Sum of & & & Mean & & \\
\hline Model & & Squares & Df & & Square & $\mathrm{F}$ & Sig. \\
\hline 1 & Regression & 346.723 & & 2 & 173.362 & 17.443 & $.000^{\mathrm{b}}$ \\
\hline & Residual & 377.667 & & 38 & 9.939 & & \\
\hline & Total & 724.390 & & 40 & & & \\
\hline
\end{tabular}

a. Dependent Variable: students'achievement

b. Predictors: (Constant), students' perception on scientific approach student attitude

Based on table IV.12. it means the significant value is less than $0.05(0.000<0.05)$. There is a linear regression of student English achievement and student perception on scientific approach and attitude can be used as predictors at their English achievement. Table above explains whether there is influence or not of students' attitude and perception toward English achievement, the score of "sig" in the table above indicates the significant influence of perception toward English achievement. Based on the table above, it can be seen from score of "sig is lower than 0.05, sig. $0.000<0.05$ so, it means that there is influence of attitude and perception toward English achievement. The table above also shows that the analysis of variance for multiple regression data produced an $\mathrm{F}$ ratio of 17.443. This indicates that the effectiveness of the independent variables in predicting the academic achievement of students could not have been due to chance. Then, it can be concluded that the two factors are relevant in predicting and improving the English achievement of the students. The purpose of this study is to examine the influence of Students' Attitude and perception on implementing the scientific approach toward English Achievement at SMA Muhammadiyah 11 Padangsidimpuan. The purpose of this research is elaborated into three research questions. The first research question is "Is there any significant influence of students' attitude on implementing scientific approach toward their English achievement at SMA Muhammadiyah 11 Padangsidempuan? The finding of data analysis is that there is significant influence of students' attitude toward their English achievement.

The second research question is "Is there any significant influence of students' perception on implementing scientific approach toward their English achievement? The finding of data analysis is that there is significant influence of students' perception toward their English achievement. The third research question is "Is there any significant influence of students' attitude and perception on implementing scientific approach toward their English achievement? The finding of data analysis is that there are significant influence of students' attitude and perception using scientific approach in teaching and learning process toward students' English achievement at SMA Muhammadiyah 11 Padangsidempuan. Based on the main research question above, it can be divided into some minors' research questions. These research questions stated as follow:

In order to answer objectives of the research about the influence of attitude toward English' achievement Pearson Product Moment Correlation analysis was conducted. As the finding of this study showed that there was a significant influence of students 'attitude (0.678) toward students' English achievement. It can be known from the score of sig. $<0.05$. Score of "sig." was 0.000 . It also can be seen from the mean score of attitude was 80.04 and the mean score of achievement was 76.12. It meant that if the students had positive attitude, 
they would have high achievement. This result is similar with result of Inal, Evin and Saracaloglu (nd: 38), their study indicates that there is a significant relation between student academic achievement and student attitude towards foreign language. Moreover, the results of the present study are consistent with the study of Soleimani \& Hanafi (2013), Abidin, et al. (2012), Alsolaibi \& Alsaifi (2012), and Saracaloğlu (2004), in which they stressed the correlation between student attitude and academic achievement.

Then, to determine about the influence of students' perception toward English achievement the Pearson Product Moment Correlation analysis was also used. The result of analysis showed that the value of Pearson correlation was 0.663, the value of Sig. (2-tailed) was 0.000 . It also can be seen from students perception mean score (78.97) and achievement was (76.12), it indicated that if students had high perception, they would have a high achievement. The similar result from Saeed (2015: 667) she found that perception and academic achievement have mutual influence on each other, and research shows that creative people have more and better academic achievement. These findings are similar to those found in other studies in which perception proved to be an important correlate of academic achievement Ai, 1999; Atkinson, 2004; Fortner, 1986; Naderi, Abdullah. Another statement by Bano et al (2014: 604) state that academic achievement and perception are not only positively related to each other but are also highly correlated.

Lastly, to find out about the influence of students' attitude and perception toward English achievement the multiple regressions analysis was also used. As the result of the study, the value of Sig. (2-tailed) < 0.05, the Sig. was 0.000. It also can be seen from the total of mean score of students' attitude and perception $((80.04+78.97=79.505)$ and the mean score of achievement was 76.12. It is proved that, if students have positive and high perception, their achievement also will be high. Furthermore, the scientific approach of curriculum 2013 covers three competencies of attitude, skill and knowledge. Learning outcomes are able to produce students become productive, creative, innovative and effective through the integration of the strength of attitude, skill and knowledge. The aspect of attitude makes the students able to transform the teaching materials in order to lead them "why to know", and the aspect of competency makes the students able to transform the teaching materials and the students able "how to know"; the aspect of knowledge makes the students able to transform the teaching materials and the students able "what to know", and the last result is to improve and to make the students to have balance between soft skill and hard skill which covers the aspects of attitude, skill and knowledge competencies (Guidelines of Curriculum 2013).. It can be inferred that positive attitude owned by the students can lead the students to obtain optimal good learning achievement when the attitude is integrated with two other competencies, skill and knowledge. Attitude is everything and it is the most important aspect owned by the learners in teaching and learning process.

Attitude is the first aspect in teaching and learning process. As Muslim students, it is very crucial to integrate with Islamic moral values and information technology that make the students successfully and effectively implemented in teaching and learning process as it is demanded in curriculum 2013. The students should be aware of and understand the positive interdependence and individual accountability elements. (Hasan: 2014).

\section{CONCLUSION}

The main of the research was to find out the influence of students' attitude and perception through scientific approach toward their English achievement at the eleventh grade of SMA Muhammadiyah 11 Padangsidempuan. There were three research questions in this research; The result of research findings, the first finding of the research indicated that there was a positive influence between students' attitude through scientific approach toward students' English achievement which was proved by interpreting the result of correlation 
where the value of pearson correlation is 0.678 , the value of Sig. (2-tailed) is 0.000 , and total number of students is 41 . By looking at the value of Sig. (2-tailed), it can be said that there is a significant correlation between students' attitude and achievement, and also the value of pearson correlation, it is higher than ttable by comparing it at significant level $5 \%$ or $0.678>$ 0.347. The second finding, there was a positive influence between students' perception through scientific approach toward English achievement which was showed that the value of pearson correlation is 0.663 , the value of Sig. (2-tailed) is 0.000 , and total number of students is 41. By looking at the value of Sig. (2-tailed), it can be said that there is a significant correlation between students' perception through scientific approach and English achievement, and also the value of pearson correlation, it is higher than ttable by comparing it at significant level $5 \%$ or $0.663>0.347$. The last finding, there was a positive influence between students attitude and perception through scientific approach toward their English achievement was proved by seeing the score of "sig" Is lower than 0.05 , sig. $0.000<0.05$ so, it means that there is significant influence of students' attitude and perception through scientific approach toward their English achievement.

Thus, based on the result finding, it can be concluded that the higher students' attitude, the higher score of students' English achievement would be, while lower of students' attitude, the lower of the students' English achievement would be. Then, the students' English achievement was also influenced by students' perception through scientific approach. The higher the students' perception the higher the students' English achievement

\section{REFERENCES}

Abidin. M.J.Z., Pour-Mohammadi, M., \& Alzwari, H. (2012). EFL Students' Attitudes towards Learning English Language: The Case of Libyan Secondary School Students: Asian Social Science. Vol. 8, No. 2.

Albalawi, Raghian, B. (2014). Student Attitudes toward Intensive English Program at CSCED and their Effects on Academic Achievement. International Journal for Innovation Education and Research: Vol.2-10.

Alkaff, A. (2013). Students' Attitudes and Perceptions towards Learning English. AWEJ. Volume.4 Number.2.

Al samadani, Hasem A and Ibnian, Salem S. 2015. The Relationship between Saudi EFL Students' Attitudes towards Learning English and their Academic Achievement. International Journal of Education and Social Science. www.ijessnet.com. Vol. 2 No. 1.

Arikunto, S. 1998. Prosedur Penelitian : Suatu Pendekatan Praktik. Jakarta: Rineka Cipta.

Atchade, M, P. 2001.The Impact of Learners' Attitudes on Second or Foreign Language Lerning. Sciences Sociales et Humanies. Rev. Cames. Serie B, Vol 004.

Awang.M. M., et al (2013). Students' Attitudes and Their Academic Performance in Nationhood Education: International Education Studies. Vol. 6, No. 11.

Ba-Udhan. H.S.A. (2011). Impact of Students' Attitudes on their Achievement in English: A Study in the Yemeni Context. Volume 11 : 2. ISSN 1930-2940. 
Brown, H. Douglas. 2000. Principles of Language Learning and Teaching. New York: Person Education.

Chaihiranwattana. M \& Nookua. S. (nd). An Investigation on English Language Learning Attitude of Siam University Students.

Chapman, Elwood N. and Mcknight, Wil. (2004). Attitude: Your Most Priceless Possession. India: Crisp Publications, Inc.

Choy, S. C. \& Troudi, S. (2006). An investigation into the changes in perceptions of and attitudes towards learning English in a Malaysian college. International Journal of Teaching and Learning in Higher Education, 18(2), 120-130. [Online] Available: http://www.isetl.org/ijtlhe.

Colak, A. (2008). Attitude, Motivation and Study Habit of English Language Learners: The Case Baskent University Second Year Students.

Dehbozorgi, E. (2012). Effects of Attitude towards Language Learning and Risk-taking on EFL Student's Proficiency. International Journal of English Linguistics, 2(2), 41-48. http://dx.doi.org/10.5539/ijel.v2n2p41.

Dimyati, Mudjiono. 2006. Belajar dan Pembelajaran. Jakarta: PT. Rineka Cipta.

Dornyei, Z. (2005). The psychology of the language learner: Individual differences in second language acquisition. Mahwah, NJ: Lawrence Erlbaum.

Ellis, L. (2002). Teaching from experience: a new perspective resolution on the nonnative teacher in Adult ESL. Australian Review of Applied Linguistics, 25(1), 71-107.

Furchan, Arief. (2007) Pengantar Penelitian dalam Pendidikan.Yogyakarta: Pustaka Pelajar Offset

Gardner, R. C. (2005). Integrative motivation and second language acquisition; Canadian Association of Applied Linguistics/Canadian Linguistics Association Joint Plenary Talk - May 30, 2005, London, Canada. Retrieved from http://publish.uwo.ca/ gardner/newestvita.pdf

Gardner, R. C. (1985). Social psychology and second language learning: The role of attitudes and motivation.London: Edward Arnold Publishers.

Hanerson, E. Morris, L \& Fitz-Gibbon, C. 1987. How to measure Attitude: The Regents of the University of Calofornia: California.

Hatch, E and Farhady, H. 1982. Research design and statistics for applied linguistics. London: Newbury House Publisher.

Hornby, A. S. 1995. Oxford Advanced Learner's Dictionary. Oxford University Press. 
Hosseini, S, B., \& Pourmandnia, D. (2013). Languge Learner's Attitude and Beliefs: Brief Review of the Related Literature and Framworks: International Journal on New Trends in Education and Their Implications. ISSN 1309-6249.

Inal, S., Evin, I, \& Saracaloglu. A.S. (nd). The Relationship between Students' Attitude toward Foreign Language and Foreign Language Achievement.

Gajalakshmi. (2013). High School Students' Attitude toward Learning English Language: International Journal of Scientific and Research Publications. Volume 3, Issue 9. ISSN 2250-3153.

Garnder R. C \& Lambert W. E (1972). Attitudes and Motivation in Second Language Learning. Newbury: Massachusetts.

Jonassen, D. \& Missouri. (2000). Learning: as Activity.

Khoir, M. (2014). The Language Attitude of Students of English Department UIN SunanKalijaga toward English. Yogyakarta. http://digilib.uinsuka.ac.id/11503/2/BAB\%20I,\%20IV,\%20DAFTAR\%20PUSTAKA.pdf

Mar'at (1982). Sikap Manusia, Perubahan serta Pengukurannya. Bandung Ghalia Indonesia.

Martos, R, M,C. (2004). Second language acquisition Psychological factors, Affective/emotional factors. Aldadis.net La revista de educación. Depósito Legal: AL61_2004 ISSN: 1697-8005

Mc. Millan, J. (1992). Educational research: Fundamentals for the consumer. New York,NY: Harper Collins Publisher.

Morgan, R. (1989). An examination of the relationship of academic course work with admissions test performance (College Board Report No. 89-6). NY: College Entrance Examination Board. (ERIC Document Reproduction Service No. ED 315 441)

Muthanna, A \& Miao, P. 2015. Chinese Students' Attitudes towards the Use of Englishmedium Instruction into the Curriculum Courses: A Case Study of a National Key University in Beijing. Journal of Education and Training Studies Vol. 3, No. 5. ISSN 2324-805X E-ISSN 2324-8068 Published by Redfame Publishing URL: http://jets.redfame.com.

Nabila, A. (2015). Personality and Learning Creativity of the Students with English Learning Achievement: Jolliet, Vol. 2, No. 1.

Naderi, H., Abdullah, R., Aizan, H. T., Sharir, J., \& Kumar, V. (2009). Creativity, age and gender as predictors of academic achievement among undergraduate students. Journal of American Science, 5(5), 101-112.

Ostrom, T.M., et al. (1994). Attitude Scales: How to Measure the Unmeasurable.Persuasion: Psychological Insights an Perspectives. Ed. Shavitt and T.C. Brock. Boston: Allyn and Bacon, 15-42.

Payne, D.A. (2003). Applied Educational Assessment (2nd edition). London: Thomson Learning. 
Rani, G., \& Dalal, S., (2013). Relationship of Creativity and Achievement Motivation of Senior Secondary Students: International Journal for Research in Education. ISSN:2320-091X. Vol. 2, Issue:7.

Rivero, L. (2014). When It Comes to Creativity, Attitude Is Key. Online source: https://www.psychologytoday.com/blog/creative-synthesis/201404/when-it-comescreativity-attitude-is-key. Accessed: 10 November 2015.

Samadani \& Ibnian, S. S. (2012). Group Work and Attitudes of Non-English Major Students towards Leaning EFL, International Journal of Humanities and Social Science Vol. 2 No. 4, pp. 192-198.

Saracaloğlu, S.(2004). The Relationship Between Students' Attitudes Toward Foreign Language And Foreign Language Achievement. Approaches to the Study of Language and Literature. (Paper Presentation) First International Conference DokuzEylül University Buca Faculty of Education, 1-3 October, zmir.2004.

Schuder, K. (2015). How to Build a Positive Attitude Online source: http://www.wikihow.com/Build-a-Positive-Attitude.

Soleimani, H. \&Hanafi, S.(2013). Iranian Medical Students' Attitud towards English Language Learning. International Research Journal of Applied and Basic Sciences. Available online at www.irjabs.com ISSN 2251-838X / Vol, 4 (11): 3816-3823 Science Explorer Publications, Department of Applied Linguistics, Payame Noor University, Iran.

Suharto, G. (2003). Metodologi Penelitian Pendidikan Bahasa. Jakarta: Departemen Pendidikan dan Kebudayaan.

Sudjana. 1992. Metode Statistika. Bandung: Tarsita.

Sudjana. Nana. 2005. Penilaian Hasil Proses Belajar Mengajar. Bandung: PT. Remaja Rosdakarya.

Suryabrata, Sumadi. 1989. Psikologi Pendidikan. Jakarta: CV. Rajawali.

Toth, Zs. (2011). Foreign Language Anxiety and Advanced EFL Learners: An Interview Study. Working Papers in Language Pedagogy, 5, 39-57.

Wallen, N.E., \& Fraenkel, J.R. (1991). Educational research: A guide to the process. NewYork, NY: McGraw Hill, Inc.

Walqui, A. (2000). Access and engagement: Program design and instructional approaches for immigrant students in secondary schools (McHenry, IL, and Washington DC.: Delta Systems and Center for Applied Linguistics.

Winkel, W.S. (1991). Psikologi Pengajaran . Jakarta: Gasindo

Zafarghandi. A.M., \& Jodai, H.(2012). Attitudes toward English \& English learning at an Iranian Military. Guilan University-Iran.

(nd). Psychology of Education (PDE 106). Module 2. 